\title{
PENERAPAN METODE DEMONSTRASI UNTUK MENINGKATKAN KETERAMPILAN MERANGKAI PERALATAN DESTILASI
}

\section{APPL YING THE DEMONSTRATION METHOD TO IMPROVE SKILLS OF DISTILLATION EQUIPMENT ASSEMBLY}

\author{
Siti Nurjanna $\mathbf{1}^{\star}$ \\ 1) SMK-SMTI Pontianak, Jl. Sulawesi Dalam No.31, Pontianak \\ *e-mail: citynurjanna30@gmail.com HP: 082250111771
}

Submit 9 Juni 2020, Revisi 18 Juni 2020, Terbit 31 Desember 2020

\begin{abstract}
A teacher must be able to involve her students to find the materials that they are studying It may encourage the students to apply the materials in their daily lives. The problem faced by the students of SMK-SMTI Pontianak concerned the misconceptions in the assembly of distillation equipment. They also got confused when installing condenser hoses for the line and the direction of cooling water. It was identified that when doing their practicum, the students only read the work instruction on the jobsheet without any demonstration. To overcome the problem, the teacher needs to apply the demonstration method. This research aimed to investigate whether the demonstration method could improve the students' skill in distillation equipment assembly. It was a Classroom Action Research (CAR) that consisted of 2 cycles. The research subjects were 16 students grouped in XIF. The technique and the instrument of the data collection were an observation technique and test respectively. The data were analysed qualitatively. It is found out that the demonstration method improved the students' skills in assembling the distillation equipment. The skill improved $18.75 \%$ from $75 \%$ in Cycle I to $93.75 \%$ in Cycle II; or the average score increased 9, that is, of from 76 in the first cycle to 85 in the second cycle In conclusion, the application of demonstration method improved the students' skills of distillation equipment assembly.
\end{abstract}

Keywords: demonstration, destillation, assembly skills

\section{ABSTRAK}

Guru harus mampu melibatkan siswa dalam proses pembelajaran untuk menemukan materi yang dipelajari sehingga dapat mendorong siswa untuk menerapkannya di kehidupan sehari-hari. Permasalahan yang terjadi di SMK khususnya SMK-SMTI Pontianak adalah adanya miskonsepsi siswa dalam merangkai peralatan destilasi. Selain itu, siswa merasa kebingungan ketika memasang selang kondensor untuk jalur dan arah air pendingin. Hal ini disebabkan karena saat praktikum siswa hanya membaca instruksi kerja pada jobsheet tanpa adanya peragaan. Untuk mengatasi permasalahan tersebut dapat diterapkan metode demonstrasi. Penelitian ini bertujuan untuk meningkatkan keterampilan merangkai peralatan destilasi melalui metode demonstrasi. Penelitian ini merupakan Penelitian Tindakan Kelas (PTK) yang terdiri dari 2 siklus. Obyek penelitian adalah siswa kelas XI F yang berjumlah 16 siswa. Teknik pengumpulan data menggunakan observasi dan tes keterampilan merangkai peralatan destilasi. Teknik analisis data menggunakan analisis kualitatif. Hasil penelitian menunjukkan terjadi peningkatan keterampilan merangkai peralatan destilasi dengan menerapkan metode demonstrasi. Ketuntasan belajar pada siklus I sebesar $75 \%$ dan meningkat menjadi $93,75 \%$ pada siklus II sehingga besar peningkatan yaitu $18,75 \%$. Nilai rata-rata keterampilan siswa meningkat dari 76 pada siklus I menjadi 85 pada siklus II sehingga besar peningkatan yaitu 9. Dengan demikian disimpulkan bahwa penerapan metode demonstrasi dapat meningkatkan keterampilan merangkai peralatan destilasi siswa.

Kata kunci: demonstrasi, destilasi, keterampilan merangkai 


\section{PENDAHULUAN}

Pemilihan metode pembelajaran siswa baik secara individual atau secara kelompok harus tepat, agar pelajaran itu dapat diserap, dipahami, dan dimanfaatkan oleh siswa dengan baik. Selain itu, dalam pembelajaran, guru harus mampu melibatkan siswa secara penuh agar siswa dapat memahami materi yang dipelajari dan dapat menghubungkannya dengan situasi kehidupan nyata sehingga siswa dapat menerapkannya dalam kehidupan sehari-hari. Dengan demikian, selain penguasaan konsep, prinsip, dan hukum kesetimbangan, guru juga harus mengaitkan materi dan praktikum yang diajarkan dengan situasi dunia industri.

Berdasarkan pengamatan terhadap proses pembelajaran, permasalahan yang dihadapi oleh siswa di SMK-SMTI Pontianak adalah materi destilasi yang sulit dipahami oleh siswa. Penyebabnya adalah sebelum praktikum, siswa harus mengingat atau menghapal jenis-jenis alat yang akan dirangkai, cara merangkai peralatan destilasi serta memasang selang air pendingin masuk dan keluar dengan benar (tidak terbalik posisinya). Selain itu, pada saat praktikum siswa hanya membaca instruksi kerja pada jobsheet tanpa adanya peragaan suatu kegiatan sehingga siswa menjadi bingung ketika merangkai peralatanperalatan destilasi dan salah memasang selang pada kondensor untuk jalur atau arah air pendingin yang masuk dan yang keluar. Akibatnya, banyak siswa yang tidak tuntas dalam pembelajaran. Hal tersebut dibuktikan dengan rekapitulasi nilai hasil belajar siswa dengan Kriteria Ketuntasan Minimal (KKM) yang ditetapkan adalah 75 , namun pada kompetensi destilasi siswa kelas XI F tahun pelajaran 2014/2015 rata-rata persentase siswa tidak tuntas adalah $36,50 \%$.

Permasalahan di atas dapat diatasi salah satunya dengan penerapan metode demonstrasi. Menurut Syah (2000) metode demonstrasi adalah metode mengajar dengan cara memperagakan barang, kejadian, aturan, dan urutan melakukan suatu kegiatan, baik secara langsung maupun melalui penggunaan media pengajaran yang relevan dengan pokok bahasan atau materi yang sedang disajikan. Pembelajaran menggunakan metode demonstrasi tergolong efektif bagi siswa. Melalui metode ini siswa ditunjukkan pada proses peristiwa, mulai dari awal hingga akhir. Metode demonstrasi memberikan contoh yang diperagakan kepada siswa dengan tujuan memberikan pemahaman terhadap terjadinya suatu peristiwa, dan melatih siswa untuk mempraktikkannya (Abizar, 2017). Oleh karena itu, metode demonstrasi adalah pembelajaran dengan cara memperagakan konsep atau suatu proses kepada siswa.

Menurut Suprijanto (2012), metode demonstrasi memiliki kelebihan yaitu, (1) menarik perhatian siswa, (2) menghadirkan subjek dengan cara yang mudah dipahami, (3) bersifat nyata, (4) meyakinkan hal-hal yang bersifat meragukan, (5) menunjukkan pelaksanaan ilmu pengetahuan dengan contoh, (6) mempercepat penyerapan langsung dari sumbernya, dan (7) memberikan bukti.

Keterampilan berarti kecakapan untuk menyelesaikan tugas (Depdikbud, 1990). Sudarto (2016) berpendapat bahwa keterampilan adalah kemampuan teknis untuk melakukan suatu perbuatan. la merupakan aplikasi atau penerapan dari pengetahuan teoritis yang dimilik 
seseorang, seperti keterampilan bercocok tanam bagi petani, mengajar bagi guru, membuat kursi bagi tukang kayu, memotong dan menjahit baju bagi penjahit, dan lain-lain. Dengan keterampilan, seseorang dapat melakukan suatu pekerjaan secara efektif dan efisien.

Penjelasan di atas dapat disimpulkan bahwa pembelajaran yang dilakukan dengan mendemonstrasikan suatu proses kepada siswa akan menyebabkan siswa lebih memahami materi yang diajarkan (khususnya materi yang akan dipraktikumkan). Dengan demikian, ketika siswa menguasi suatu proses maka dapat meningkatkan keterampilan siswa tersebut.

Ada beberapa peneliti yang melaporkan bahwa metode demonstrasi dapat meningkatkan keterampilan siswa. Misalnya, (1) Nawir dkk. (2015) menyebutkan, "Penerapan metode pembelajaran demonstrasi dapat meningkatkan keterampilan melukis peserta didik Kelas XII IPA 3 SMA Negeri 1 Donri Kabupaten Soppeng yakni dari 57.11 pada siklus I dan 78.44 pada siklus II"; dan (2) Sukerti dkk. (2014) menyebutkan, "Penerapan metode demonstrasi dengan menggunakan media gambar berseri untuk meningkatkan keterampilan menulis narasi siswa kelas V Semester 1 SDN 3 Dencarik Kecamatan Banjar, Kabupaten Buleleng Tahun Pelajaran 2012/2013 dimana keterampilan menulis narasi siswa meningkat dari siklus I sebesar $64,0 \%$ ke siklus II sebesar $72,5 \%$ dari kriteria sedang menjadi tinggi".

Tujuan dari penelitian yang dilakukan adalah untuk meningkatkan keterampilan siswa merangkai peralatan destilasi setelah diajar melalui metode demonstrasi. Adapun metode demonstrasi dalam penelitian ini adalah guru memperagakan cara merangkai peralatan destilasi berdasarkan jobsheet sebelum siswa melakukan praktikum.

\section{METODE}

Jenis penelitian ini adalah peneltian tindakan kelas. Penelitian ini menggunakan model penelitian tindakan dari Kemmis dan Taggar, yang terdiri dari empat tahap yaitu planning (perencanaan), action (pelaksanaan), observation (pengamatan), reflection (refleksi) (Melissa, 2016). Pada penelitian ini dirancang dengan menggunakan model siklus yang terdiri dari 2 siklus. Desain rancangan penelitian seperti gambar 1 .

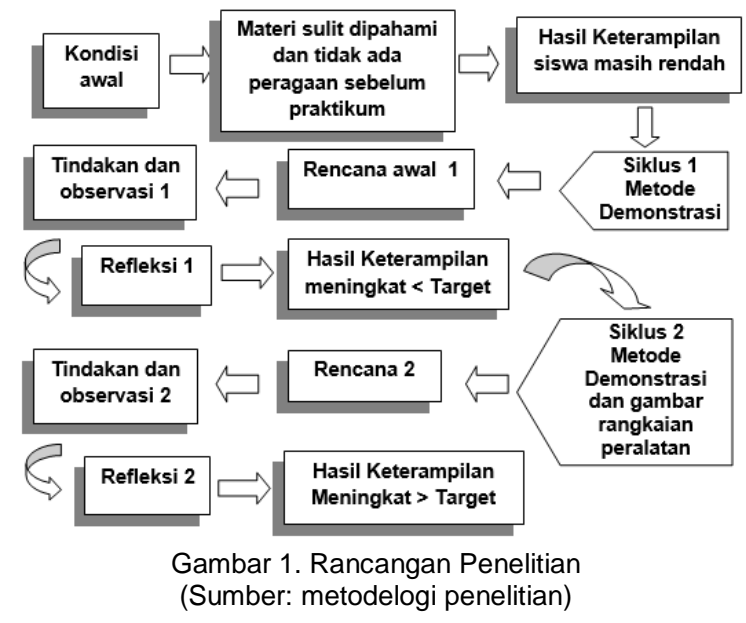

Penelitian dilakukan di SMK-SMTI Pontianak pada bulan November sampai dengan Desember 2015. Obyek penelitian yaitu kelas XI F Kimia Industri SMK-SMTI Pontianak, dengan jumlah siswa sebanyak 16 orang. Pada penelitian ini, data dikumpulkan melalui teknik pengamatan atau observasi dan dengan tes keterampilan merangkai peralatan destilasi. Data dianalisis secara kualitatif. 


\section{HASIL DAN PEMBAHASAN}

Proses pembelajaran dalam penelitian ini yaitu pembelajaran dengan metode demonstrasi dimana pembelajaran dilakukan dengan 2 siklus. Setiap siklus terdiri dari tahap perencanaan tindakan, tahap pelaksanaan tindakan, tahap observasi tindakan, dan tahan refleksi tindakan. Nilai indikator keberhasilan terdiri dari $85,00 \%$ untuk ketuntasan dan 75 untuk nilai rata-rata kelas. Metode demonstrasi pada Siklus I dilakukan dengan cara: (1) mempersiapkan peralatan destilasi sesuai dengan jobsheet, (2) mendemonstrasikan merangkai peralatan destilasi yang akan dicapai, (3) memberikan kesempatan kepada siswa untuk melakukan demonstrasi, (4) memberikan bimbingan kepada siswa pada saat demonstrasi, dan (5) mengevaluasi hasil kerja siswa.

Komponen penilaian keterampilan merangkai peralatan destilasi dapat dilihat pada Tabel 1.

Tabel 1. Komponen Penilaian Kemampuan Merangkai Peralatan Destilasi

\footnotetext{
No Komponen Kemampuan Merangkai Peralatan Destilasi

1. Mendata kebutuhan peralatan yang akan digunakan untuk destilasi

2. Mendata kebutuhan bahan yang akan digunakan untuk destilasi

3. Membuat rencana tahapan proses destilasi

4. Mengidentifikasi jenis alat yang akan digunakan untuk destilasi dengan benar.

5. Menentukan jumlah alat yang sesuai dengan kebutuhan

6. Memilih peralatan utama destilasi dengan benar

7. Memilih alat pendingin dengan benar

8. Memilih pemanas untuk membuat steam dengan benar
}

9. Memilih peralatan pendukung yang digunakan dalam destilasi

10. Memeriksa dan meyakinkan peralatan destilasi layak dipakai

11. Memeriksa dan meyakinkan alat pendingin layak dipakai

12. Memeriksa dan meyakinkan pemanas untuk membuat steam layak dipakai

13. Memeriksa dan meyakinkan alat pendukung berfungsi dengan baik

14. Membersihkan peralatan destilasi dengan alat dan bahan dengan benar

15. Membersihkan alat pendingin dengan alat dan bahan dengan benar

16. Membersihkan pemanas untuk membuat steam dengan alat dan bahan dengan benar

17. Membersihkan peralatan pendukung dengan alat dan bahan dengan benar

18. Memakai pelindung tangan sesuai dengan benar

19. Memakai masker dengan benar

20. Memakai jas laboratorium dengan benar

21. Memakai sepatu kerja laboratorium dengan benar

22. Menutup alat destilasi dengan rapat

23. Menyiapkan air sebagai air pendingin yang akan dialirkan dalam kondensor dengan benar

24. Menempatkan kondensor pada posisi yang benar

25. Merangkai kondensor dengan memasang selang air pendingin masuk dan selang air pendingin keluar dengan benar

26. Memastikan sirkulasi air pendingin masuk dan keluar kondensor lancar

27. Pemanas steam ditempatkan pada tempat yang sesuai

28. Erlenmeyer diletakkan pada posisi yang benar

Sumber: instrumen penelitian

Adapun hasil keterampilan merangkai peralatan destilasi pada siklus I dapat dilihat pada Tabel 2. 
Tabel 2. Hasil Keterampilan Merangkai Peralatan Destilasi Pada Siklus I

\begin{tabular}{lc}
\hline & Siklus I \\
\hline Nilai Maksimum & 85 \\
Nilai Minimum & 61 \\
Nilai Rata-Rata & 76 \\
\hline
\end{tabular}

Sumber: data penelitian

Tabel 2 menunjukkan bahwa nilai rata-rata pada Siklus I adalah 76 .

Ketuntasan merangkai peralatan destilasi antara Siklus I dapat dilihat pada Gambar 2.

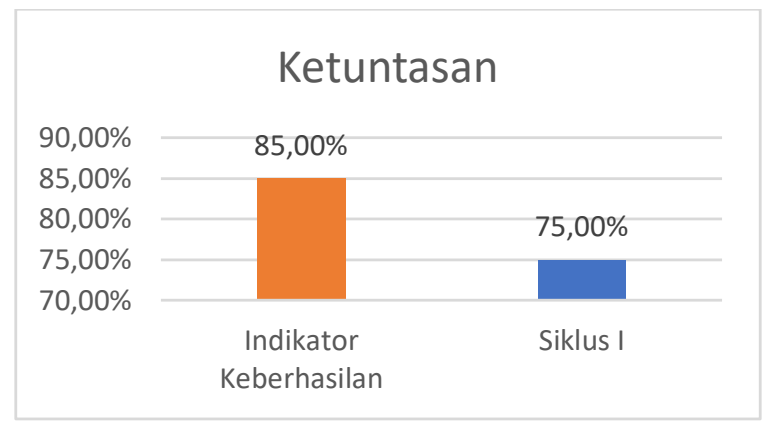

Gambar 2. Ketuntasan Merangkai Peralatan Destilasi Pada Siklus I

Gambar 2 menunjukkan bahwa ketuntasan merangkai peralatan destilasi pada Siklus I adalah 75,0 \%.

Pelaksanaan penelitian Siklus I belum menunjukkan keberhasilan penelitian. Hal tersebut ditunjukkan dengan ketuntasan siswa 75,00\%, walaupun nilai rata-rata kelas lebih besar dari indikator keberhasilan yaitu, 76 .

Penerapan metode demonstrasi pada Siklus I belum berhasil. Hal ini disebabkan oleh masih adanya siswa yang tidak memahami bagian-bagian dari peralatan destilasi akan terjadi kesalahan ketika siswa merangkai peralatan. Ketidakberhasilan pada Siklus I juga terjadi karena proses pembelajaran belum sesuai dengan yang diharapkan dimana sebagian besar siswa belum berpartisipasi dengan maksimal. Hal tersebut tampak ketika peneliti menjelaskan dan mendemonstrasikan cara merangkai peralatan destilasi, terlihat sebagian siswa yang kurang fokus bahkan tidak memperhatikan guru. Begitu pula demonstrasi yang dilakukan oleh siswa juga kurang serius ketika kegiatan demonstrasi.

Ketidakberhasilan Siklus I mengharuskan peneliti untuk melakukan Siklus II, yang merupakan hasil refleksi dari kegagalan dan kekurangan pada Siklus I. Pada siklus II dilakukan perbaikan terhadap proses pembelajaran yang masih membutuhkan perbaikan pada Siklus I. Tahapan yang dilakukan oleh peneliti untuk memaksimalkan pembelajaran pada pada Siklus II yaitu, (1) merancang kembali rencana pembelajaran, (2) membuat RPP dengan memperjelas peran dan fungsi siswa dalam pembelajaran dengan penerapan metode demonstrasi, (3) membuat jobsheet dengan melampirkan gambar alat, dan (4) menyiapkan instrumen penilaian dan lembar observasi. Selain itu, peneliti juga melakukan bimbingan lebih pada siswa yang kurang aktif atau pun siswa yang tampak belum serius dan main-main dalam kegiatan demonstrasi pada pembelajaran Siklus I.

Pada Siklus II, guru juga mempersiapkan alat-alat yang digunakan untuk demonstrasi, merumuskan tujuan yang akan dicapai dengan metode demonstrasi, mengemukakan langkah-langkah metode demonstrasi kepada siswa. Selanjutnya peneliti mendemonstrasikan terlebih dahulu keterampilan merangkai peralatan destilasi yang akan dicapai, kemudian memberikan kesempatan kepada siswa untuk melakukan demonstrasi. Pada Siklus II ini, peneliti 
juga memberikan bimbingan lebih kepada siswa pada saat kegiatan demonstrasi serta melakukan evaluasi terhadap hasil kerja siswa. Pembimbingan ini dilakukan pada siswa yang terlihat mengganggu temannya ataupun tidak memperhatikan pada saat proses pembelajaran berlangsung sehingga siswa tersebut lebih berpartisipasi dalam proses pembelajaran.

Adapun hasil keterampilan merangkai peralatan destilasi pada siklus II dapat dilihat pada tabel 3 .

Tabel 3. Hasil Keterampilan Merangkai Peralatan Destilasi Pada Siklus II

\begin{tabular}{lc}
\hline & Siklus II \\
\hline Nilai Maksimum & 95 \\
Nilai Minimum & 73 \\
Nilai Rata-Rata & 85 \\
\hline Sumber : data peneliti &
\end{tabular}

Tabel 3 menunjukkan bahwa nilai rata-rata pada siklus II adalah 85 .

Ketuntasan merangkai peralatan destilasi antara siklus II dapat dilihat pada Gambar 3.

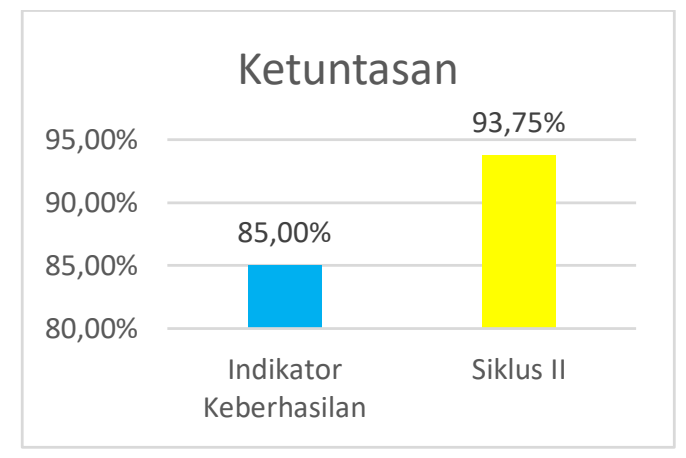

Gambar 3. Ketuntasan Merangkai Peralatan Destilasi Pada Siklus II

Gambar 3 menunjukkan bahwa ketuntasan merangkai peralatan destilasi pada Siklus II adalah $93.75 \%$.

Pelaksanaan penelitian Siklus II sudah sesuai harapan. Hal tersebut ditunjukkan dengan ketuntasan siswa
$93,75 \%$ dan nilai rata-rata kelas lebih besar dari indikator keberhasilan yaitu 85. Oleh karena itu, penelitian dihentikan pada Siklus II karena indikator keberhasilan pada Siklus II telah tercapai.

Keberhasilan penelitian pada Siklus II ini menunjukkan bahwa penerapan metode demonstrasi sangat tepat diterapkan pada keterampilan merangkai peralatan destilasi karena menekankan proses aktivitas dan partisipasi siswa di dalam proses pembelajaran di kelas, serta menuntun siswa untuk memahami keterampilan tertentu melalui kegiatan demonstrasi. Hal ini sesuai yang dikemukakan oleh Djamarah dan Zain (2010) bahwa metode demonstrasi adalah cara penyajian pelajaran dengan memperagakan atau mempertunjukan kepada siswa suatu proses, situasi atau benda tertentu yang sedang dipelajari, baik sebenarnya ataupun tiruan yang sering disertai dengan penjelasan lisan. Pernyataan tersebut sesuai dengan hasil penelitian yang dilakukan oleh peneliti bahwa adanya kegiatan demonstrasi yang dilakukan sangat membantu siswa dalam memahami merangkai peralatan destilasi dengan baik. Hal tersebut juga terlihat pada aktivitas siswa sebelum diberi perlakuan, dimana siswa cenderung kurang memperhatikan dan bersikap tak acuh terhadap pembelajaran. Melalui metode demonstrasi siswa terlihat memperhatikan dengan seksama dan aktif bertanya. Hal ini dikarenakan siswa melihat langsung peragaan merangkai peralatan destilasi serta memperagakan kembali merangkai peralatan destilasi. Hal tersebut juga didukung oleh Yuliana dkk. (2014) yang mengemukakan, "diperoleh aktivitas siswa dalam proses pembelajaran ilmu pengetahuan alam pada pokok bahasan susunan dan fungsi 
bagian tumbuhan dengan metode demonstrasi yang paling dominan adalah mendengarkan atau memperhatikan penjelasan guru, serta memperagakan media yang siswa miliki. Jadi dapat dikatakan bahwa aktivitas siswa dikategorikan aktif."

\section{KESIMPULAN}

Penerapan pembelajaran dengan metode demonstrasi dapat meningkatkan keterampilan siswa pada mata pelajaran Operasi Teknik Kimia (OTK) materi Merangkai Peralatan Destilasi kelas XI F SMK-SMTI Pontianak tahun pelajaran 2015/2016 dengan persentase ketuntasan belajar pada siklus I sebesar $75,00 \%$ dan pada siklus II meningkat menjadi $93,75 \%$ dan nilai rata-rata keterampilan siswa juga meningkat dari 76 pada siklus I menjadi 85 pada Siklus II.

Saran yang dapat peneliti sampaikan berdasarkan hasil penelitian yang telah dilakukan sebagai berikut: (1) penerapan pembelajaran dengan metode demonstrasi disarankan untuk diterapkan dan dikembangkan dalam pembelajaran praktikum destilasi karena berdampak positif terhadap peningkatan keterampilan dalam merangkai peralatan destilasi dengan benar, (2) kepada peneliti selanjutnya agar menerapkan pada kompetensi OTK lainnya seperti ekstraksi dan filtrasi, dan (3) perlu adanya penelitian lebih lanjut untuk jenjang pendidikan SD/Sederajat dan SMP/Sederajat.

\section{REKOMENDASI}

Hasil penelitian menunjukkan bahwa metode demonstrasi dapat meningkatkan keterampilan siswa. Hal tersebut dikarenakan metode demonstrasi sangat cocok diterapkan pada materi/kompetensi yang di dalamnya terdapat kegiatan praktikum sehingga siswa lebih tertarik melihat langsung suatu peragaan dibandingkan dengan hanya sekedar membaca materi dalam proses pembelajaran. Oleh karena itu, peneliti merekomendasikan kepada peneliti lain untuk menggunakan metode demonstrasi dalam proses pembelajaran. Peneliti juga merekomendasikan metode demonstrasi untuk digunakan sebagai bahan acuan bagi pemerintah dalam mengembangkan metode yang tepat dalam dunia pendidikan.

\section{UCAPAN TERIMA KASIH}

Selama melakukan penelitian ini, peneliti ucapkan terima kasih kepada kepala sekolah SMK-SMTI Pontianak yang telah memfasilitasi kegiatan penelitian ini, guru-guru yang selalu mendoakan kelancaran penelitian serta observer dalam hal ini guru sejawat yang selalu memberikan masukan dalam penelitian ini.

\section{DAFTAR PUSTAKA}

Abizar, H. (2017). Buku Master Lesson Study. Diva Press.

Depdikbud. (1990). Kamus Besar Bahasa Indonesia. Balai Pustaka.

Djamarah, S. B., \& Zain, A. (2010). Strategi Belajar Mengajar. Rineka Cipta.

Melissa, M. M. (2016). Peningkatan Kemandirian Dan Prestasi Belajar Matematika Dengan Pendekatan Problem Based Learning (PBL) Di Kelas VII E SMPN 15 Yogyakarta. Jurnal IImiah Edukasi Matematika, 2(1), 1-18.

Nawir, Arafah, K., \& Pristiwaluyo, T. 
(2015). Penerapan Metode Demonstrasi untuk Meningkatkan Keterampilan Melukis Peserta Didik Kelas XII IPA 3 SMA Negeri Donri Donri Kabupaten Sopeng. Jurnal Pendidikan dan Evaluasi Pendidikan, 1(1), 1-8.

Sudarto. (2016). Keterampilan dan Nilai Sebagai Materi Pendidikan dalam Perspektif Islam. Jurnal Al-Lubab, 1(1), 105-120. http://jurnal.fkip.uns.ac.id/index.php/ pip/article/view/7506/5363.

Sukerti, N. K. S., Agustina, I. G. A. T., \& Pudjawan, K. (2014). Penerapan Metode Demonstrasi Dengan Menggunakan Media Gambar Berseri Untuk Meningkatkan Keterampilan Menulis Narasi Siswa Kelas V Semester 1 Sdn 3 Dencarik Kecamatan Banjar, Kabupaten
Buleleng Tahun Pelajaran 2012/ 2013. MIMBAR PGSD Undiksha, 2(1), 1-10. https://ejournal.undiksha.ac.id/index .php/JJPGSD/article/view/2639.

Suprijanto. (2012). Pendidikan Orang Dewasa Dari Teori Hingga Aplikasi. PT.Bumi Aksara.

Syah, M. (2008). Psikologi Pendidikan Dengan Pendekatan Baru. Remaja Rosda Karya.

Yuliana, Heryana, N., \& Yani, A. (2014). Meningkatkan Hasil Belajar Dengan Metode Demontrasi Pada Materi Susunan Dan Fungsi Bagian Tumbuhan. Jurnal Untan, 3(4), 116.

http://jurnal.untan.ac.id/index.php/jp $\mathrm{dpb} /$ article/view/5163 